\title{
Chapter 6 \\ Extending Social Insurance Schemes to "Non-Employees": The Dutch Example
}

\section{Gijsbert Vonk}

\section{Introduction}

The digital age is one of the drivers that results in a shift away from standard employment and towards various new forms of flexible employment, a process which represents a wider problem for the labour market and for society as a whole. ${ }^{1}$ As for the Netherlands, this country is already a champion of flex work. It was one of the largest growers in the EU for both temporary work and solo self-employment with 4.7 percentage points of growth in the 10 years prior to $2018 .^{2}$ With a 30 percent flex share of workers, the Netherlands occupied third place in 2018 in the EU, with only Poland and Spain - which have a particularly high percentage of temporary workers - having a larger share of flexible work. Greece, where the share of self-employed persons in agriculture is particularly high, has almost as much flexible work as the Netherlands. ${ }^{3}$ There are many factors that explain this trend, including typically Dutch institutional factors. These include: the liberal registration policy of self-employment by the Dutch Tax and Customs Administration prior to 2016, generous fiscal exemptions for

1 Digital Labour Platforms and the Future of Work: Towards Decent Work in the Online World, International Labour Office - Geneva, ILO, 2018, https:/www.ilo.o rg/wcmsp5/groups/public/---dgreports/---dcomm/---publ/documents/publication/wc ms_645337.pdf. Accessed 16 August 2020; Pesole, Annarosa/Urzi Brancati, Cesiral Fernández-Macías Enrique/Biagi, Federico/González Vázquez Ignacio, Platform Workers in Europe, EUR 29275 EN, Publications Office of the European Union, Luxembourg, 2018, doi:10.2760/742789, JRC112157, http://publications.jrc.ec.europa.eu/r epository/handle/JRC112157. Accessed 17 April 2020.

2 Information from the Dutch Statistical Bureau CBS based on Eurostat data, https:// www.cbs.nl/nl-nl/dossier/dossier-flexwerk/hoofdcategorieen/flexwerk-in-nederlanden-de-eu. Accessed on 17 April 2020.

3 Information from the Dutch Statistical Bureau CBS based on Eurostat data, https:// www.cbs.nl/nl-nl/dossier/dossier-flexwerk/hoofdcategorieen/flexwerk-in-nederlanden-de-eu. Accessed on 17 April 2020. 
the self-employed, and previous labour law reforms which regulated (and in doing so: facilitated) flexible employment relationships. ${ }^{4}$

The digital economy may result in an increase and diversification of flexible work forms due to platform activities ${ }^{5}$ and changes in production methods in general. It may also expose groups of lower- and middle-income earners to labour-related risks, in particular unemployment; traditional factory workers are replaced by robots and administrative personnel are made redundant due to the introduction of the latest smart computer applications. Indeed, while technological change and the shift to flexible forms of employment have long been heralded as something positive for both the economy and society, there is now growing evidence that there are also negative effects to be taken into account. Thus, in a recent report written for the Netherlands Independent Commission on the Regulation of Work, the OECD noted that the solo self-employed are less productive than employees with equivalent characteristics. Moreover, it was pointed out that high shares of non-standard employment (combined with strict employment protection legislation on standard contracts) may lower the resilience of labour markets to economic shocks since such contracts are more cyclical in nature. Furthermore, it was pointed out in the OECD research that, because many non-standard workers are worse off in many aspects of job quality, such as earnings, job security or access to training, a rise in non-standard employment tends to contribute to higher inequality. ${ }^{6}$

These and other drawbacks that have come to the fore have resulted in a growing consensus in the Netherlands' policies that the trend towards flexible work has gone too far, or at least that something must be done to strengthen the position of those who do not work in standard full-time

4 Eindrapport Interdepartementaal Beleidsonderzoek Zelfstandigen zonder personeel, https:/www.rijksoverheid.nl/documenten/rapporten/2015/10/02/eindrapport-i bo-zelfstandigen-zonder-personeel. Accessed on 25 September 2020.

5 Cf. inter alia Schoukens, Paul/Barrio, Alberto/Montebovi, Saskia, The EU Social Pillar: An Answer to the Challenge of the Social Protection of Platform Workers?, in: European Journal of Social Security, 20 (2018) 3, pp. 219-241, https://journals.sage pub.com/doi/full/10.1177/1388262718798393.

6 OECD Input to the Netherlands Independent Commission on the Regulation of Work, summarized in Annex 5 of Commissie Borstlap. In at voor land willen we werken. Naar een nieuw rapport voor de regulering van werk. Eindrapport van de Commissie voor de Regulering van Werk (Commissie Borstlap), 23 January 2020, https:/www.rijksoverheid.nl/documenten/rapporten/2020/01/23/rapport-in-wat-vo or-land-willen-wij-werken. Accessed 16 August 2020. 
employment. ${ }^{7}$ This growing consensus affects both labour law and social security law and the way these two areas are linked.

The purpose of this contribution is to offer a broad overview of the Netherlands' state of protection of non-standard workers (defined as everyone without a permanent contract of employment) under social security law. The objective is to map out what new approaches have been taken into consideration in order to fill protective gaps for these persons. It is divided into three parts:

(1) a description of the present state of social security law (Section III);

(2) an analysis of policy objectives, legislative change and proposals for change made by successive governments in the Netherlands and by official advisory agencies since 2010 (Section IV); and

(3) an overview of lessons that may (not) be learned from the Dutch experience (Section V).

These three parts are preceded by a short description of the Netherlands' system and the logical setup of this contribution connected to this system (Section II). The last Section V dealing with the lessons can also be read as a conclusion. This contribution focuses on public social security law. While regular excursions to (individual and collective) labour law and fiscal law are required, these fields of law are not the subject of separate analysis.

\section{The System in the Netherlands and Logical Setup of this Contribution}

The Dutch social security system bears the marks of different schools of thought, preferences and approaches in the history of European social security. Pre-war social security was in keeping with the continental, corporate approach, which was reflected in the first social insurance schemes that were based on the involvement of employer and employee organisations at sectoral level. After World War Two, social insurance was influenced more by the Beveridge approach to social security. This is visible in the emergence of national insurance, in Dutch: volksverzekeringen. This is a system of residence-based schemes that are based on the insurance principle and provide minimum income protection. National insurance schemes

7 Brink, Barbara/Vonk, Gijsbert, Naoorlogs universalisme in het huidige socialezekerheidsdebat, in: Beleid \& Maatschappij, 47 (2020) 2, pp. 149-168, https://doi.org/10. 5553/BenM/138900692020047002004. Accessed 16 August 2020. 
in the Netherlands have been introduced for the risks of old age (AOW 1957), death (AWW 1959, currently Anw), children (AKW 1972), incapacity for work (AAW 1975) and special medical expenses (ABWZ 1976, currently Wlz). The present public/private insurance system for curative care $(\mathrm{Zvw})$ can also be characterised as a national insurance scheme.

No national insurance schemes have been created to cover unemployment and sickness. Instead, there are employee insurance schemes (WW and $\mathrm{ZW}$ ). The Sickness Benefit Scheme (ZW) is partly replaced by a civil law liability for the employee to continue to pay wages for an extended period of two years (Article 7: 629 Civil Code). The risk of incapacity for work currently also falls within the exclusive scope of an employee insurance scheme (the WIA Act, the Dutch Work and Income (Employment Capacity) Act). The former national insurance for incapacity for work (AAW) was abolished in 1998; it survived some time as a separate insurance scheme for the self-employed until that scheme was also abolished in 2004.

A system of social assistance and social care creates a general non-contributory safety net. The 21 st century also marks the start of social allowances being paid through the taxation system. These social-fiscal allowances are paid by the Dutch Tax and Customs Administration and are gradually reduced as employees earn more. Allowances are paid as compensation for rent, healthcare contributions, childcare and children. These allowances fall under the regime of uniform concepts in the Awir (Dutch General Act on Income-Related Schemes). They are also fully residencebased.

The above description sets the scene for the further composition of this contribution. For it has to be borne in mind that, in principle, the whole problem of social security protection for non-standard workers does not exist in areas where national insurance schemes (and universal social fiscal allowances) have been established. The reason is that these are residencebased schemes and do not make any distinction between employees and the self-employed or, for that matter: between those who are economically active and those who are not. This observation also largely holds true for the financing of this part of the system. Contributions for the general social insurance schemes (with the exception of the curative care insurance $\mathrm{Zvw}_{\mathrm{vw}}$ are integrated within the system of general income tax and are, as such, levied by the taxation authorities. All income from non-wage labour is subject to both national insurance contributions and general taxation liability. As there is a separate contribution liability for employee insurance schemes, there is a need to qualify the income as either generated from wage labour or non-wage labour. But within this wide band of non-wage 
labour all income from any economic activity is taken into account. There are no minimal income thresholds. The liability for taxation and national insurance contributions may be reduced by a number of tax credits. It is possible that for persons on low income the amount of tax credits which they are entitled to is higher than the amount of tax. In such cases, a person cannot fully offset their tax credits with the tax he or she has to pay. At least this is the case for single persons. When a person has a fiscal partner the situation may be different, when that partner earns an income which is high enough to incorporate the combined tax credits.

The foregoing implies that the problem of social security protection for non-standard workers in the Netherlands can be defined with reference to three major issues: 1) demarcation between those who are considered to be employees for the purposes of the employee insurance schemes and those who are not, i.e. the category of the self-employed at large (necessitated by the fact that there is a mixed system of employee and national insurance schemes and, parallel to that, between wage tax and general income tax); 2) protection against the risks for which only employee insurance schemes have been established (i.e. unemployment, sickness and incapacity for work); and 3) coverage for extra-minimal protection for old age and death through the occupational pension system (in view of the fact that the national insurance schemes for old age (AOW) and for death (Anw) only provide flat rate minimum subsistence benefits, which in the Netherlands system are supplemented by wage-related additions to be accrued on the occupational pension system).

The description of the present state of social security law for non-standard workers in the next section is set up according to this order. Thereby it has to be borne in mind that the analysis cannot always be limited to social security law, as there are important linking pins in the legal regime with both labour law and fiscal law.

\section{The Present State of Social Security Law for Non-Standard Workers}

\section{Demarcation between Those Who are Considered to be Employees and Those Who are Not}

In first instance, the distinction between employees and self-employment plays a specific role in the employee insurance schemes set up for the risks of illness (ZW), incapacity for work (Wet WIA) and unemployment (WW). Employees are insured under the employee insurance schemes. An employee is a natural person who has concluded an employment contract 
under private or public law and has not yet reached standard retirement age. ${ }^{8}$

\section{a) Main Rules}

An employment relationship under public law is based on an appointment by a public body. These employees are called civil servants. An employment relationship under private law is a relationship based on an employment contract as defined in the Dutch Civil Code. Whether or not the employment relationship has these features is dependent on the three classical criteria of personal work, wage and subordination. Employment practices operate on the basis of a variety of non-standard forms of employment. Only the agency contract is regulated in the Dutch Civil Code as separate from the general employment contract (Article 7:690 Civil Code). Other forms of non-standard employment, such as part-time work, on-call work, etc. are directly dealt with under the general employment contract rules set out in Article 7:610 Civil Code.

\section{b) The Role of Case Law}

Traditionally, it is pointed out that the Dutch Social Security Court $(\mathrm{CRvB})$ uses a different basis than the Civil Court in establishing whether or not there is an employment relationship. Whereas the Civil Court attaches more importance to the parties' intentions when determining their employment relationship, the $\mathrm{CRvB}$ focuses on the factual relationship existing between the parties. In doing so, the CRvB aims to stop parties from acquiring a benefit or being granted a waiver of contributions on the basis of the contractual relationship. However, the significance of this difference in approach between the two courts should not be overemphasised. Recent years have seen a trend towards more convergence. ${ }^{9}$

But apart from this, jurisprudence is very much meandering and developing on a case-by-case basis. This can be illustrated by the case law on the status of post distributors, triggered by the FNV trade union. The largest postal company, PostbedrijfNL had traditionally resorted to employees

8 Article 3 (1) ZW, Article 3 (1) WW, Article 3 (1) WAO and Article 8 (1) Wet WIA.

9 Cf. Klosse, Saskia/Vonk, Gijsbert, Hoofdzaken socialezekerheidsrecht, The Hague: Boom Juridische Uitgevers 2019, pp. 67-70. 
working for a wage but suddenly introduced a new business model in which the post deliverers were required to conclude contracts for services as solo self-employed workers with the company. Many courts ruled this to be a bogus construction but on appeal the Arnhem-Leeuwarden Court of Law $^{10}$ and the Amsterdam Court of Law ${ }^{11}$ confirmed that the solo self-employed workers did indeed deliver post for Post $N L$ as solo self-employed workers. According to the courts, the parties' intention as well as the actual performance of the work indicated that the parties' wanted to conclude a contract for services.

Another illustration of the ad hoc nature of the jurisprudence is the case law on Deliveroo personnel, also initiated by the FNV trade union. On 23 July 2018, the Amsterdam District Court was of the opinion that a Deliveroo worker does not have an employee status in view of the clear intention of the parties expressed in the agreement ${ }^{12}$, but on 15 January 2019 the Court changed its mind and reached the decision that such a worker is deemed to be an employee, this time going beyond the mere formal expression of the intention of the parties and carefully looking at the material conditions of the case $\mathrm{e}^{13}$. For example, in the latter case, the formal possibility of replacement by another person was disregarded because replacement did not occur in practice.

c) Extending and Limiting the Scope of Application of the Employee Insurance Schemes on the Basis of Legal Fiction

The definition of "employee" for the purpose of the employee insurance schemes is not limited to employees who are employed on the basis of a private or public employment contract. It also includes persons working in other employment relationships. These employment relationships are treated in the same way as employment relationships in which employee insurance is compulsory. The term "fictitious employment relationship" or "employment relationship by legal definition" is then used. Article 4 of the Dutch Sickness Benefits Act/Unemployment Act (ZW/WW), for example, stipulates that an employee is the person who performs work for which he or she has been contracted, unless he or she can be qualified as a self-em-

10 ECLI:NL:GHARL:2016:6621.

11 ECLI:NL:GHAMS:2016:2686.

12 ECLI:NL:RBAMS:2018:5183.

13 ECLI:NL:RBAMS:2019: 189 and 2010. 
ployed entrepreneur in the fiscal sense. In specific circumstances intermediaries are also treated as employees. Article $5 \mathrm{ZW} / \mathrm{WW}$ extends the concept of employee further to musicians, professional sportsmen and women and homeworkers, at least inasmuch as they are not already classified as employees under private law.

These groups that are also brought within the scope of the employee insurance schemes are referred to in Dutch as "rariteiten", or rarities. A statutory instrument called the Rariteitenbesluit regulates the conditions under which the scope of the employee insurance schemes is extended to include special groups. Examples of these groups are: small contractors for work, intermediaries and their agencies (commercial agents, representatives etc.), share-fishermen, interns, conscripts, executives of cooperative societies, homeworkers and their agencies, musicians and artists, professional sportsmen and sportswomen and the remaining group of "people performing professional services". Sex workers are also included. Inasmuch as flexible workers qualify themselves as one of these groups and meet the set requirements, they are included in the insurance.

The most diverse group of people to whom the scope of the employee insurance schemes is extended, is a residual category of "people performing professional services". To qualify for compulsory insurance, several conditions have to be met. For instance, the scope of the work relationship is subject to certain minimums in terms of the number of working hours or duration of the work and earnings (at least 40 percent of the statutory minimum wage).

Finally, for the sake of completeness, it must be noted that the employee insurance acts do not only allow for an extension of insurance to persons without an employment contract. There are also general exclusions applying to persons who do have such a contract. Thus, persons working fewer than four days a week in a private person's household fall outside the scope of the employee insurance schemes (Article 6 (1c) ZW/WW): cleaners, gardeners and home carers, etc.

\section{d) No (Formal) Definition of "Self-Employed Worker"}

While there is a (not so) clear definition of "employee" for the purposes of both labour and social security law, a similar definition of a "self-employed person" is notably absent in the Netherlands. The self-employed work on the basis of different contracts is regulated in the Civil Code, i.e.: 1) overeenkomst tot aanneming van werk, i.e. producing work of a physical nature such as in construction (Civil Code Article 7:750) and 2) overeenkomst 
van opdracht, i.e. commissioned work (Civil Code Article 7:400). The second contract form is the dominant one for the self-employed. Despite the absence of a positive legal definition of self-employment, a number of positive indications have developed in the administrative practice of the tax authorities which play a major role in the practical assessment of the person's status as employed or self-employed. Below in the final part of this subsection I will pay further attention to this.

e) Practical Assessment of the Nature of the Employment Relationship by the Taxation Authorities

In practice, the distinction between being defined as an employee or as a self-employed person may not be an easy one. In order to offer more certainty, the taxation authorities play an important role in certifying the employment relationship. This system of certification, however, has run into rough political weather. The former system of registration of self-employed workers that was in force until 1 May 2016, i.e. the "VAR" (Declaration of Independent Contractor Status), imposed the risk of a wrongful registration on the employee. This made it attractive to employers to use (bogus) self-employed workers rather than employees working for a wage. In order to overcome this problem, the Wet DBA (Wet Deregulering Beoordeling Arbeidsrelaties - Act on the Deregulation of Judging Working Relationships) entered into force on 1 May 2016. This act introduces a system of prior mandatory certification of the employment relationship by the taxation administration. This new legislation shifted the risk for a wrongful assessment of the employment relationship from the employee to the employer. Amidst increasing legal uncertainty as to how employment relationships had to be qualified and due to a variety of implementation problems, the operation of the new act was soon suspended, pending the construction of yet another new assessment system. At the time of writing, this is still the case. In the meantime, employment relationships are not actively monitored by the tax authorities and enforcement measures are limited to manifestly fraudulent situations.

Generally speaking, the tax administration makes use of a variety of criteria for establishing employee insurance contribution liability and payroll tax liability. The criteria are set out in the Handreiking beoordelingskader arbeidsrelaties (guidelines for assessing employment relationships) ${ }^{14}$. These el-

14 www.belastingdienst.nl. 
ements are derived from tax and social security law (which in their turn partly refer to labour law definitions). Examples are, inter alia: registration with the Chamber of Commerce, profit, the number of hours spent working for a company, the possibility of replacement, capital investment, entrepreneurial risk in the case of no payment, the number of customers, and how he or she actively presents him- or herself as a self-employed person to the public.

\section{Protection of the Self-Employed against the Risks for which only Employee} Insurance Schemes have been Established (i.e. Unemployment, Sickness and Incapacity for Work)

\section{a) Sickness}

Solo self-employed workers are not entitled to continued payment during illness, nor can they apply for a sickness benefit on the grounds of ZW. For a safety net in the event of sickness solo self-employed workers today have to rely on private insurance (referred to as AOV) or alternatively join a broodfonds (literally: bread fund). Below, both options will be described.

Self-employed workers seeking to take out private incapacity-for-work insurance (AOV) have to go through a technical and medical acceptance procedure. In the first case, the insurance company assesses what conditions it will attach to the insurance and whether it indeed wishes to offer insurance. The insurer offers AOV insurance based on the principle that the insurer is free to decide to do so or not, as long as this does not contravene mandatory legislation, for example on non-discrimination. During the medical acceptance procedure, the medical adviser's assessment plays a major role. This defines the risk. The insurer then establishes whether the self-employed worker seeking insurance is eligible for AOV and if so, under what conditions. The medical adviser must be in a position to act objectively and independently of the insurer and, on the basis of Article 7:435 of the Dutch Civil Code, the adviser should duly observe the professional medical standard. Generally speaking, the self-employed worker seeking insurance has no choice and will have to accept the examination. While the contribution rate and the amount and duration of the benefit formally depends on what is agreed between the parties, in practice there is no room for negotiation for the self-employed worker. Four out of every five solo self-employed workers have not taken out AOV, usually because they find this too expensive. Solo self-employed workers who are insured pay 
contributions of around 7 or 8 percent of their annual income. ${ }^{15}$ Research conducted by the Social and Economic Council (SER) in the Netherlands shows that to receive a benefit of EUR 32,000 a year, contributions of about 15 percent have to be paid.

Due to the high cost of private insurance, broodfondsen are increasingly seen as the better alternative. ${ }^{16}$ They are an intriguing phenomenon emerging from civil society initiatives. The funds are set up by a mutual agreement between small groups of solo self-employed workers in various occupational branches, designed to provide income protection during sickness of one or more of the members (for up to a maximum of two years). A group of self-employed workers deposit a specific amount each month on their own bank account. How much this is depends on the benefit they will need in the event of sickness. When a member falls ill, he or she can receive an annuity from the fund, the level of which depends on their deposits into the fund. When a member leaves the fund, their deposits in the fund are returned. An individual can only join such a fund after being introduced by a participant. The maximum size of a fund is 50 participants, in order to maintain the small-scale character which allows for mutual trust. The broodfondsen are new, but at the same time reminiscent of the types of mutual aid that came into being in the guilds and similar institutions a long time ago. This approach remains a relatively marginal, but continuously expanding phenomenon. ${ }^{17}$

\section{b) Unemployment}

There is no private insurance for the self-employed against unemployment. Indeed, according to the Bond van Verzekeraars, the umbrella organisation of private insurers, this risk does not lend itself to private insurance. There are merely some residual forms of protection for the self-employed in the public WW scheme. Thus, for example, unemployed persons who aim to

15 Pension Advice 2017/85.

16 Hilhort, Pieter, Sociale veerkracht als vangnet, in: s\&d, 5 (2011) 6, p. 151.

17 In April 2020, there were about 562 broodfondsen for more than 20,000 persons. Between 2010 and 2018, the broodfondsen paid out in total almost EUR 3.1 million to 452 solo self-employed workers who had fallen ill. This is EUR 6,800 per person. The average duration of the incapacity for work was almost six months, cf. Broodfondsen: de stand van zaken, 1 April 2020, https://www.broodfonds.nl/n ieuws/nieuws/broodfondsen_de_stand_van_zaken. Accessed 17 April 2020. 
start their own company in self-employment, can take advantage of the Starters' Scheme (Article 77a WW).

\section{c) Incapacity for Work}

When the various national insurance schemes were established, self-employed workers were not included in the mandatory insurance schemes against long-term incapacity for work. However, in the 1970s this was increasingly seen as a shortcoming in view of the universal ambitions of the social security project. This culminated in the General Act on Incapacity for Work (AAW). While there were few thresholds for access to (partial) invalidity benefit, married women who were not the breadwinner of the family were excluded. When EU law opened the gates for this group to join the AAW, the system became untenable. In 1998, the act was replaced by two schemes, one of which was for self-employed workers: the Self-Employed Persons Act on Incapacity for Work (WAZ). This act was to be short-lived. It was considered to be too paternalistic and too expensive. In 2004, when neo-liberalism was still running high, the WAZ was abolished. From then onwards, the self-employed were supposed to look for solutions on the private insurance market. Private insurance alternatives turned out to be not as popular as expected. It now appears that more than two out of every three self-employed workers have not taken out private insurance against incapacity for work, with a strong overrepresentation amongst the low earners. ${ }^{18}$ There is an increasing awareness that this figure, which includes large numbers of dependent self-employed workers, is not acceptable and that something needs to done to improve their protection (see below Section IV).

\section{Coverage for Extra-Minimal Protection for Old Age and Death through the Occupational Pension System}

Every resident of the Netherlands is entitled to an AOW benefit on reaching the standard retirement age, solo self-employed workers included. The

18 Klosse, Saskia, Flexibele arbeid, gebalanceerde bescherming, in: Kremer, Monique/ Went Robert/Knottnerus, André (eds.), Voor de zekerheid, de toekomst van flexibel werkenden en de moderne organisatie van arbeid, Den Haag: Wetenschappelijke Raad voor het Regeringsbeleid 2017, pp. 213-230. 
AOW pension is a flat-rate minimum benefit. For supplementary pension entitlements people have to rely on the second and third pillar pensions arrangements.

\section{a) Second Pillar}

Solo self-employed workers are usually excluded from pension systems in the second pillar. Mandatory professional pension schemes for solo selfemployed workers only exist for the medical professions and civil-law notaries. Both employees and self-employed workers participate in these professional pension funds. There are also branch pension funds for solo selfemployed workers like plasterers and painters, but these operate on a voluntary basis. Employees who continue to work in self-employment have the option to continue to save for their pension voluntarily for up to ten years. However, the contributions for this are high; the self-employed person has to pay both the employee and employer contribution. It is probably because of this that interest in this option is so low. For solo self-employed workers who do not earn business profits this option is given only for the duration of three years. In recent years, several initiatives have arisen for pension funds for solo self-employed workers. But to date, there is little interest in these facilities.

\section{b) Third Pillar}

One quarter of all solo self-employed workers has made no arrangements for their old age in the third pillar. Better pension arrangements tend to be made as the business becomes more profitable. In most cases, people save or invest, and investing in their own home is also popular. Self-employed workers do have several tax benefits in relation to their provision for old age. ${ }^{19}$ First of all, there is the annuity contribution deduction, a fiscally attractive way to save or invest for an old age benefit. In addition, advantage can be taken of the Fiscal Old Age Reserve (FOR). In 2019, up to 9.8 percent of the profit subject to a maximum of EUR 8,946 can be deducted

19 Goudswaard, Kees and Caminada, Koen, Pensioenen voor zelfstandigen, in: Kremer, Monique/Went Robert/Knottnerus, André (eds.), Voor de zekerheid, de toekomst van flexibel werkenden en de moderne organisatie van arbeid, Den Haag: Wetenschappelijke Raad voor het Regeringsbeleid 2017, pp. 231-256. 
from the profit. This is a deferred tax debt; the Tax and Customs Administration will still have to be paid later when the pension materialises. Since 2016, there is a tax concession that ensures that self-employed workers are not required to have recourse to their pension savings when they apply for social assistance. As a result of this measure it is hoped that the self-employed will start to save more, knowing that their pension is safe when they are in danger of having to rely on social assistance.

\section{Policy Objectives, Legislative Change and Proposals for Change}

\section{Fighting Bogus Self-Employment and Enforcing Labour Law Protection}

Long before 2010, the starting year of the first government led by the liberal conservative leader Mark Rutte, there were discussions about whether or not more protection and rights should be available to non-standard workers. The tone of the debate has changed over time. While during the turn of the century the flexible labour market was still often promoted as something positive for the economy and society, in subsequent years more attention was paid to the disadvantages of a flexible labour market strategy.

Due to the sharp increase in numbers, the solo self-employed are very much at the heart of the Dutch debate. The growth of solo self-employment is increasingly seen as problematic. Solo self-employment is seen as a problem for workers when the registration of the employment relationship is not correct or is bogus (schijnzelfstandigheid), or when the self-employed are highly dependent on a small number of commissioners (afhankelijke zelfstandigheid). ${ }^{20}$ The problem of dependent self-employment is most manifest in lower-paid work, because the workers lack the negotiating position to keep up a decent income. Bogus self-employment is rejected in full because it does not only impact negatively upon the protection of the lower-paid workers but also because it corrupts the foundation of tax and contribution liability.

For a long time, the debate about solo self-employment failed to result in any conclusive results, both in labour law and in social security law. In the discourse, it is often pointed out that the group of self-employed persons is very differentiated in nature, so therefore difficult to catch in uni-

20 This distinction was made by IBO 2015. 
form policy measures. ${ }^{21}$ On the one hand, it is precisely freedom and opportunities that truly self-employed workers seek and benefit from. On the other hand, there are concerns about dependent and bogus self-employed workers who are more or less forced to become self-employed because they would otherwise be made redundant. It is for the latter reason that initially policy measures have focused strongly on reducing bogus self-employment and enforcing the rules of labour law. The currently stranded initiative for the Tax and Customs Administration to introduce a new assessment system (Employment Relationships (Deregulation) Act) described earlier in Section III.1.e), is one example of such efforts.

Another example is the Act Combating Bogus Self-Employment that entered into force on 1 January 2016. Bogus self-employment is defined as the situation in which a person officially performs work as a self-employed person while the facts and circumstances indicate the existence of an employment contract. In other words, it occurs when the factual situation is different from the situation as it is presented (on paper) with the aim of improperly competing on working conditions. ${ }^{22}$ The bill for combating bogus constructions introduced inter alia an extended system to the hirers' liability. ${ }^{23}$

Also changes in the minimum wage legislation introduced in July 2017 were clearly inspired by the need to improve the possibilities for the enforcement of labour standards. While the changes extended the operation of the minimum wage legislation to more forms of marginal solo self-employment, ${ }^{24}$ they simultaneously introduced different techniques for establishing the minimum wage in order to facilitate the work of the labour inspectorate. Thus, for example, the piece-wage scheme was adjusted in such

21 Centraal Bureau voor de Statistiek, Achtergrondkenmerken en ontwikkelingen van zzp'ers in Nederland, 1 December 2014, https://docplayer.nl/13379-Achtergro ndkenmerken-en-ontwikkelingen-van-zzp-ers-in-nederland-1-12-2014-gepubliceer d-op-cbs-nl.html. Accessed 16 August 2020; Rijksoverheid. IBO-eindrapport Zelfstandigen zonder personeel, April 2015, https://www.rijksoverheid.nl/documenten /rapporten/2015/10/02/eindrapport-ibo-zelfstandigen-zonder-personeel. Accessed 16 August 2020.

22 Parliamentary papers II 2014/15, 32108, 2.

23 Set out in Article 7:616a-616f of the Dutch Civil Code which replaced Article 7:692 of the Dutch Civil Code.

24 For a more elaborate explanation, Vonk, Gijsbert/Jansen, Annette, Social Protection of Marginal Part-Time, Self-Employment and Secondary Jobs in the Netherlands, in: WSI Study No. 9, November 2017, pp. 34-35, https://www.wsi.de/de/faust-detail.htm?sync_id=7974. Accessed 16 August 2020. 
a way that it is easier to establish whether the payments made fall below the minimum wage.

\section{Confronting the Great Divide}

Gradually the concerns about bogus and dependent self-employment are being overshadowed by a wider concern about a growing gap in the Netherlands between those who have relatively stable socio-economic positions and profit from welfare growth and those who lag behind. This gap is visible in the labour market where lower-qualified workers represent a much higher share in flexible and uncertain work relationships than higher-qualified workers (dual labour market). It is also visible in society as a whole, a phenomenon which in the Dutch discourse is often referred to as the Kloof (great divide). In particular the Social and Cultural Planning Bureau (SCP) has been active in exposing this divide. Thus, for example, in an influential report published in 2014 about the divide, called Verschil in Nederland, the SCP distinguished between six groups according to their economic, social, and cultural capital characteristics. Four groups representing 70 percent of the population do relatively well. These are the established elite (15 percent), young professionals (13 percent), the working middle class ( 27 percent) and comfortable pensioners (17 percent). However, on the other side of the spectrum we find two other groups who suffer economic insecurity and various forms of social exclusion, and these are the unsecure workers ( 14 percent) and the precariat (15 percent). In this manner a "soft divide" between the have and have-nots is clearly visible.

Over the last ten years, various public advisory agencies have called for action to confront the great divide, often stressing the advantages of universalism in social protection, without, however, making this very concrete. ${ }^{25}$ In particular, the agencies refrained from explicitly addressing the "open wound" in Dutch social security for the self-employed, namely the absence of a public insurance scheme for incapacity for work, caused by the abolition of the AAW (1998) and WAZ (2004). Apparently, this was considered to be too politically sensitive or unrealistic.

A different attitude can be found amongst stakeholders and independent academics who have put forward various proposals to address the lack

25 Brink, Barbara/Vonk, Gijsbert, Naoorlogs universalisme in het huidige socialezekerheidsdebat (fn. 7), pp. 149-168. 
of social protection for non-standard workers. These range from a differentiated system of social security protection for all workers (Klosse), ${ }^{26}$ an extension of the fictitious labour relationship in the employee insurance schemes to more categories of solo self-employed and atypical workers (De Jong), ${ }^{27}$ to the introduction of a completely new labour code which regulates various categories of labour in a coherent manner (Houweling). ${ }^{28}$

The first idea has been presented by the Maastricht professor of social law, Klosse, basing herself on previous work of interdepartmental think tanks. She envisages the rules of fiscal law, labour law and social security protection as a house to which all workers have access. Once inside the house there are four different chambers, access to which depends not only on the qualification of a worker as a self-employed or employed person, but also on the degree of economic dependence, as opposed to self-reliance. Thus, economically dependent employees will be entitled to the full package of labour law and social security protection, while self-reliant self-employed persons will merely enjoy certain fiscal stimuli. But this is not the end of it because economically dependent self-employed persons will equally enjoy large sections of traditional labour law and social security protection, while those employees who are self-reliant will have less protection under labour law and opt-outs in social security.

The second idea was advocated inter alia by De Jong for platform workers in her award-winning Master thesis at the University of Groningen. The default situation for all platform workers should be that they are statutorily subject to obligatory insurance for the employee insurance scheme. Only if the platform satisfies certain predetermined statutory requirements on governance and the treatment of their workers, the platform can apply for an exemption on behalf of their workers.

The third idea is advocated by the Rotterdam professor of labour law, Houweling. He suggests that the degree of labour law and social security protection should not be dependent on the formal contractual relationship

26 Klosse, Saskia, Flexibele arbeid, gebalanceerde bescherming (fn. 18), pp. 213-230.

27 De Jong, Febe, Platformwerk als fictieve dienstbetrekking. Scriptie Rijksuniversiteit Groningen, 2 November 2018, https://www.ser.nl/nl/actueel/Nieuws/nomin aties-scripties-scriptieprijs-2020. Accessed 24 June 2020; Van den Berg, Lucy, Platformwerk, biedt het Rariteitenbesluit Soelaas?, in: Tijdschrift voor Recht en Arbeid, (2019) 15.

28 Houweling, Ruben, Modernisering van het arbeidsrecht, in: Tweede Kamer der Staten-Generaal (ed.), Ambtelijk rapport Onderzoek varianten kwalificatie arbeidsovereenkomst, pp. 91-100, https://www.tweedekamer.nl/kamerstukken/detail?id =2017D14208\&did=2017D14208. Accessed 17 April 2020 . 
but on the quality of protection itself. Thus, for example, it is clear that all workers, regardless of their status and contract form should be protected against discrimination. On the other hand, severance should only be available to those who have a contractual relationship with an employer. Houweling proposes the introduction of a Code for all Work Relations which is to not only spell out the material rules of protection but which must also specify which categories of persons come under each of these rules.

None of these initiatives have been taken up by the government. Instead, reform has rather focused on incremental changes in labour law and social security legislation. In particular, reference must be made to the Wet Werk en Zekerheid (WWZ) of 2015 (Act on Work and Security) and the Wet Arbeidsmarkt in Balans (WAB) which entered into force on 1 January 2020 (Act on a Balanced Labour Market). The first act aimed, among other things, at making the systems of flexible labour law, dismissal law and labour law more activating and to reduce the growing divide between persons with a permanent and those with a flexible contract. ${ }^{29}$ One of the reforms concerns the so-called Chain Regulation in Article 7:668a of the Dutch Civil Code, intended to prevent employers from being able to keep workers endlessly in a flexible employment relationship. The Chain Regulation limits the maximum number of temporary contracts that can be entered into consecutively and the maximum duration of these. The WWZ reduced the maximum contract duration from three to two years, thus limiting the possibilities for employers to keep workers on temporary contracts.

In many respects, the $\mathrm{WAB}$ - which followed four years later - can be seen as a technical amendment to the WWZ. This is visible in the recalibration of some rules on dismissal law and the Chain Regulation. A more substantive change involved the introduction of a new calculus for the contributions for unemployment benefits. These contributions no longer fluctuate according to the branches of industry and occupation, but according to the number of employees with a fixed-term employment contract as compared to flexible labour contracts. Employers with more flexible workers are liable to pay a higher contribution. The latter change is the first social security measure of a more radical nature with a direct financial consequence; it involves a form of pricing of flexible labour for the employers. 
In 2017, the latest government of Rutte III announced more substantive measures to confront the dual labour market by curbing the growth of solo self-employment. ${ }^{30}$ The most eye-catching proposal included in the coalition programme included the following segmentation of workers according to their level of income: workers who earn less than 125 percent of the minimum wage defined in the statute or a collective labour agreement (less than between EUR 15 and EUR 18 per hour) will be deemed to have an employment contract. The duration of the employment should be longer than three months.

This proposal never made it because it was deemed to be contrary to EU law. ${ }^{31}$ An alternative, but still substantive proposal was tabled to introduce minimum tariffs for the solo self-employed. ${ }^{32}$ According to this proposal, which is deemed not to be contrary to EU law, self-employed workers will be entitled to a minimum tariff of EUR 16 an hour. This rate is higher than the minimum subsistence norm in the Netherlands; it is calculated so as to include a number of indirect costs, such as preparation, marketing, insurance against sickness, and incapacity for work. High-earning self-employed workers (earning more than EUR 75 an hour) will be given an optout for wage tax and the employee insurance schemes. The idea, which has been widely criticised for imposing far too much red tape on small, lowerqualified solo self-employed workers, has - at the time of writing - still not been sent to Parliament in the form of a concrete legislative proposal.

Lastly, for the sake of completeness, I will mention that preparations are underway to re-introduce the presently dormant system of prior certification of the employment relationship by the tax authorities. The failed system of model agreements is to be replaced by a web module which offers commissioners of work the possibility to obtain an assessment of the nature of the employment relationship based on the answers to a number of questions raised in this module. This system is to be operational in 2021.

\section{Borstlap Commission}

Another sign that the government is prepared to contemplate more fundamental change is the initiative to charge an independent commission with

30 Vertrouwen in de toekomst' Coalition Agreement 2017-2021; VVD, CDA, D66 en ChristenUnie, 10 October 2017.

31 Parliamentary Papers II, 2018/19, 31311, No. 212.

32 Proposal for internet consultation of 28 June 2019, https://www.internetconsultat ie.nl/minimumbeloningzelfstandigen. Accessed 10 April 2020. 
a wide-reaching mandate to investigate whether the entire regulatory system for work is still up to date. The Commission, which is often referred to as the Borstlap Commission (named after its chairman Hans Borstlap) gave its verdict in its final report in January $2020 .{ }^{33}$ The shortest answer to the question raised by the government is that the regulatory framework is no longer up to date. According to the report, this threatens the economic potential of the Netherlands, ensures that groups of workers are structurally dependent on precarious and low-quality work and thus also threatens social cohesion. The Commission recommends that the Netherlands should quickly work on an integral redesign of the rules surrounding work in the areas of employment law, social security, taxation and personal development during the career. At the time of writing there is no official cabinet reaction to the report, but on the whole, it is well received in the public opinion.

Three recommendations of the Borstlap report need to be highlighted because of their direct relevance for the topic of this contribution. First of all, according to the Commission, flexible contracts should no longer be encouraged: temporary work should be truly temporary and the cost of the uncertainty should be reflected in the price of temporary work. This recommendation signals the end of decades of flexible employment strategies pursued by the respective Dutch governments. The fixed employment contract is rehabilitated as the default standard for employment relationships.

Indeed, secondly, the Commission is of the opinion that the variety of currently existing contract forms should be reduced to three forms only: dependent employment, self-employment and agency work. Cross-over forms of labour and hybrid contract forms are to be abolished. In order to avoid artificial incentives that pull labour away from its natural contract form into another, the fiscal and social security treatment of all three contract types must the equal. In other words, the price of labour may not fluctuate according to contract form.

Thirdly, the former also implies that for the risk of incapacity for work a new mandatory public insurance scheme at a minimum level for all workers must be introduced. The Commission refers to a volksverzekering, so it is better to speak of a compulsory social insurance for all residents who receive remuneration from work. Earnings-related supplements, either statutory or occupational, must complement this system. This proposal signals a change of heart in the political debate about public versus private social security which has been raging over decades. They imply a restoration and

33 Commissie Borstlap. In at voor land willen we werken (fn. 6). 
an extension of the public universal insurance system. It is expected that concrete legislative proposals to this effect will be tabled in the second half of 2020. Finally, reference is made to the proposal to introduce a universal scheme for occupational training. According to its proposal, everybody will receive a personal development budget at birth, to which employers will subsequently contribute.

\section{Conclusion: Lessons (not) to be Learned from the Dutch Experience}

From this overview it follows that in the Netherlands non-wage earners are excluded from the protection of most of the corpus of labour law and of employee insurance schemes against sickness, unemployment and incapacity for work. Neither are they likely to be covered by collective second pillar pensions which supplement the universal state pension scheme. There are exceptions for special categories of self-employed workers who enjoy limited job and social security protection. These are diverse groups like artists, franchise holders, sales agents, homeworkers, etc.

As mentioned in the introduction, over the last decades the Netherlands has experienced a sharp increase in both solo self-employment and flexible employment. This can partly be explained by measures to encourage flexibility on the labour market, leading inter alia to the liberal registration policy of self-employment by the Dutch Tax and Customs Administration prior to 2016, generous fiscal exemptions for the self-employed, and previous labour law reforms which regulated (and in doing so: facilitated) flexible employment relationships. We have seen that growth in non-standard labour is increasingly seen as problematic. While attention focused initially mostly on the problem of bogus self-employment and lack of social protection for individuals who occupy a place in the lower echelons of the flexible labour market, the concerns have gradually shifted to the detrimental effects of a dual labour market on the economy and society as a whole. Reducing flexible work and bringing it back to its very essence is now seen as a way of confronting the great divide between stronger and weaker groups of citizens and as a way of investing in human capital.

This shift is reflected in the nature of the measures successive governments have taken or have contemplated. Initially, these measures were mostly practical, focusing for example on offering more legal certainty by introducing a certification of employment relationship by the tax authorities and combating bogus self-employment by simplifying legislation and strengthening enforcement measures. More recent measures are more robust in character, including a system of minimum tariffs for the self-em- 
ployed and introducing forms of pricing of flexible labour. If it is up to the Borstlap Commission, the reforms should spill over to structural changes in the regulation of labour, but if and how these ambitions will materialise in the post COVID 19-era remains to be seen. At the time of writing, i.e. at the height of the coronavirus crisis, the government priority has been to respond to the economic effects of this crisis by introducing a temporary income support regime for the self-employed who are faced with a reduction or cessation of business activity. For our subject of social security, the most exciting prospect will be the re-emergence of a universal scheme for basic protection against incapacity for work, which had existed until 1998 (and further in its revised form until 2004). The abolition of the universal scheme for incapacity for work around the turn of the century has proven to be a historical anomaly. If this is to be translated into a lesson, it is: Do not temper with broad solidarity institutions, because once abolished they are very hard to reintroduce.

Another lesson is that it is worthwhile to continue to invest in a properly functioning registration system of work relationships. Despite all its mishaps and teething problems, the binding registration may qualify as an interesting practice from a comparative point of view. This is because the registration system does not only provide legal certainty, but can also operate as a steering instrument to regulate employment relationships in a proactive manner according to policy objectives pursued. Thus, for example, when the feeling is that solo self-employment should be tested more vigorously in relation to the traditional criteria of the employment contract, this can be done by changing how authorities judge the labour relationship as part of the registration system. While the previously existing system of the VAR-verklaring failed to realise this ambition because it was too liberal and shifted the burden of wrongful registration too much to the worker, the new system of so-called model agreements (which seeks to address these wrongs) failed because of implementation problems. But this does not mean to say that the system cannot work. Arguably, the new approach should be given time and space to be tried out. The latest government of Rutte III is taking its time. It announced the development of a new web module in 2017 which should give clarity to employers/commissions of work of the status of the worker as employee or self-employed worker. But at the time of writing, the module is still not fully in operation. However, there are first signs of hope. The web module has completed its test phase and is now entering its first pilot phase. In a letter to Parliament of 15 June 2020, the Minister of Social Affairs reported to Parliament that the test phase shows that the web module provides clarity in a large number of cas- 
es. ${ }^{34}$ Only in 25 percent of the cases the commissioners of work received a declaration of self-employment. In 27 percent of the cases the web module could not create sufficient clarity, but in 48 percent of the assignments, the web module indicated employment, which means that an employment contract is probably required. This last relatively large percentage could be seen as an indication that the web module steers employment relationships in the direction of the employment contract, or at least that it does not bias in favour of solo self-employment in the way that the previous system of VAR declarations did. Indeed, the Minister warned that companies who wanted to establish working relationships with self-employed workers should structure such relationships differently in the future. Perhaps the web module can also work as a stepping stone towards the creation of more legal certainty for platform workers, in the sense that platforms who engage such workers and who use the web module will realise in time that the workers do not necessarily have the status of solo self-employed workers merely due to the fact that they work for platforms.

34 Cf. Voortgangsbrief werken als zelfstandige, Minister van Sociale Zaken en Werkgelegenheid, 15 June 2020, https://www.rijksoverheid.nl/actueel/nieuws/202 0/06/15/webmodule-zzp-start-als-pilot. Accessed 25 September 2020. 
